\section{Intersections}

Canadian Journal of Music

Revue canadienne de musique
Intersections CANADIAN JOURAL OF MUSIC
REVUE CANADIENEE DE MUSIOUH

\title{
Dark Mirrors and Dead Ringers: Music for Suspense Films about Twins
}

\section{Durrell Bowman}

Volume 27, numéro 1, 2006

URI : https://id.erudit.org/iderudit/1013161ar

DOI : https://doi.org/10.7202/1013161ar

Aller au sommaire du numéro

\section{Éditeur(s)}

Canadian University Music Society / Société de musique des universités canadiennes

\section{ISSN}

1911-0146 (imprimé)

1918-512X (numérique)

Découvrir la revue

Citer cet article

Bowman, D. (2006). Dark Mirrors and Dead Ringers: Music for Suspense Films about Twins. Intersections, 27(1), 54-74. https://doi.org/10.7202/1013161ar
Résumé de l'article

Cet article compare les séparations musicaux-narratives modernistes de The Dark Mirror (Robert Siodmak, 1946), Dead Ringer (Paul Henreid, 1964), Sisters (Brian De Palma, 1973) et les fusions musicaux-narratives post-modernistes du film canadien Dead Ringers (David Cronenberg, 1988). Les deux films les plus anciens (mettant en vedette respectivement Olivia de Havilland et Bette Davis) sont en conformité avec l'esthétique du film noir ou " suspense-thriller » alors que les deux plus récents (mettant en vedette respectivement Margot Kidder et Jeremy Irons) contiennent également des éléments substantiels d'" horreur ». Les trames musicales de ces quatre films (composées par Dimitri Tiomkin, André Previn, Bernard Herrmann et Howard Shore) mettent en évidence, à des degrés divers, le positionnement approprié et le développement de leitmotifs et de thématiques musicales, des changements de significations par modifications de l'instrumentation et-ou du mode, des représentations par genre et des marques établissant une hiérarchie culturelle et des distinctions de classes.
All Rights Reserved (C) Canadian University Music Society / Société de musique des universités canadiennes, 2007
Ce document est protégé par la loi sur le droit d'auteur. L'utilisation des services d'Érudit (y compris la reproduction) est assujettie à sa politique d'utilisation que vous pouvez consulter en ligne.

https://apropos.erudit.org/fr/usagers/politique-dutilisation/ 


\section{Dark Mirrors and DeAd Ringers:}

\section{Music For Suspense Films about Twins}

\section{Durrell Bowman}

We tend to think of our individuality in terms of body-how we look, how we sound, how we smell. With twins, that approach immediately comes into question

(David Cronenberg, 1996 Criterion laser disc edition of Dead Ringers).

In his 1988 film Dead Ringers, Canadian director David Cronenberg explores the thematic possibility of a film-music collaboration eschewing the differentiation of its primary characters in favour of their gradual fusion. The film concerns subtly different male twins who become increasingly similar, and this also involves an evocative score by the director's frequent composer and fellow Toronto native Howard Shore. The approach in Dead Ringers differs noticeably from earlier suspense films about identical twins, such as 1946's The Dark Mirror, 1964's Dead Ringer, and 1973's Sisters, in which comparatively modernist aesthetics establish one twin as psychotic, bad, or evil and the other twin as naïve, good, or at least "less bad." Those films use titles music and additional leitmotifs and other music to help separate their twins. By comparison, Shore's much more subtle music for Cronenberg's film helps to merge its twins.

Robert Siodmak's unusual film noir The Dark Mirror (1946, 85 minutes, starring Olivia de Havilland) concerns a pair of kind vs. psychotic working-class twins who involve themselves in a "psychoanalytical" cover-up having to do with the murder of a doctor who was in love with one of them. Paul Henreid's suspense-thriller Dead Ringer (1964, 115 minutes, starring Bette Davis) generally involves the aftermath of an estranged twin's revenge upon her sister for having stolen a wealthy man away from her many years earlier. Brian De Palma's psychological horror film Sisters (1973, 93 minutes, starring Margot Kidder) concerns separated Siamese twins who participate in the murder of a boyfriend and in the resultant bizarre and multi-faceted aftermath. David Cronenberg's postmodern film Dead Ringers (1988, 115 minutes, starring Jeremy Irons), involves twin male gynecologists, whose relationship degenerates into a situation where they become ensnared in a web of drug addiction, paranoia, and an eventual murder/suicide. All four films present identical twins, both of whom are portrayed by the same actor, but only Cronenberg's twins are male. This suggests that Cronenberg was sympathetic to the source story's resistance of the earlier films' participation in the more traditional "Hollywood" tendency towards characterizing strong women as erratic or psychotic. 


\section{The Dark Mirror (Robert SiodmaK, 1946)}

\section{-Q: "WAS The MirRor ME?" A: “The REFlection WAs."}

The Dark Mirror, starring Olivia de Havilland (b. 1916), is set in an unidentified U.S. city (probably a relatively smaller one) and mainly concerns the ongoing jealousy of a psychotic twin (Terry) towards her kinder, gentler twin sister (Ruth). ${ }^{1}$ The twins live together, and Terry's psychosis stems from realizing that her boyfriends and others have always actually loved Ruth's personality, so that Terry has been forced to subsume her own personality and impersonate her sister in order to connect with other people. At the beginning of the film, Terry (as becomes increasingly clear) has just killed the doctor who was the latest in the twins' long series of shared romantic interests. She attempts to deflect suspicion by manipulating naïve Ruth into not disclosing (or even believing) that she could have done this. As the unveiling of her guilt seems inevitable, Terry responds by manipulating Ruth into take sleeping pills and also causes her to believe that she is hallucinating, such as seeing lights flashing and hearing an invisible music box. However, this film by Robert Siodmak (1900-73) also contains a considerable amount of music before the appearance of that music box early in its second half.

Dimitri Tiomkin's (1894-1979) opening titles theme combines (1) an immediate, unstable leap down to a non-diatonic pitch (A-natural) plus an abrupt, chromatic ascent to another non-diatonic pitch (B natural) to represent Terry's disturbed personality and (2) a diatonically rising, much wider ranging, often rhythmically anticipatory, rubato-inflected, and generally more conventionally romantic "reflection" of this to represent Ruth's kind, accommodating personality (see Example 1).

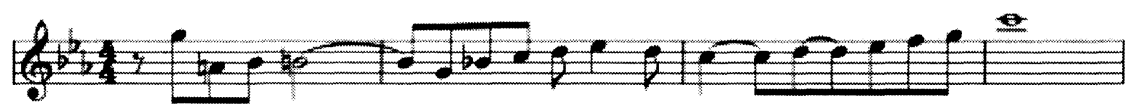

Example 1: Excerpt from the Opening Titles, The Dark Mirror; music by $\mathrm{D}$. Tiomkin, transcribed by $\mathrm{D}$. Bowman

Such a two-part theme represents the complicated "package deal" of this particular set of twins. Early in the film, music based on this accompanies Ruth's fainting when she finds out that their doctor friend has been murdered, and her reaction probably stems at least partly from suspecting that her sister could have been the murderer. Similar music accompanies Terry's success in having them share alibis so that the investigating detective, Lieutenant Stevenson (portrayed by Thomas Mitchell), cannot solve the case and the district attorney cannot successfully prosecute either of them. Ruth is clearly uncomfortable with having to maintain this deception, but she continues to go along with her sister's plan. After Stevenson leaves (having finally seen both of the twins together), Ruth becomes particularly upset, and titles-based music accompanies her sister's assurances that everything will be "fine." Stevenson does not wish to allow a murderer

1 The film was written by Nunnally Johnson, based on Vladimir Pozner's story. It was also remade for television in 1984, starring Jane Seymour. 
to get away with such a "perfect crime," and he follows this up by convincing a psychologist who studies twins, Dr. Scott Elliott (portrayed by Lew Ayres), to add Ruth and Terry into his case load. As Stevenson makes the suggestion to Dr. Elliott that the desperate murderer might try to kill her own sister, hints of Tiomkin's titles music appear. In the same scene, romantic orchestral music also reveals that Scott has more than just professional interests in mind for Ruth, as he had already been flirting with her in the twins' former job as an attendant at his medical building's newsstand. He ends up falling in love with Ruth, which should at least make us question his subsequent potential for objective research (see Figure 1). Then, towards the end of the film, he nearly becomes the latest victim of Terry's psychosis.

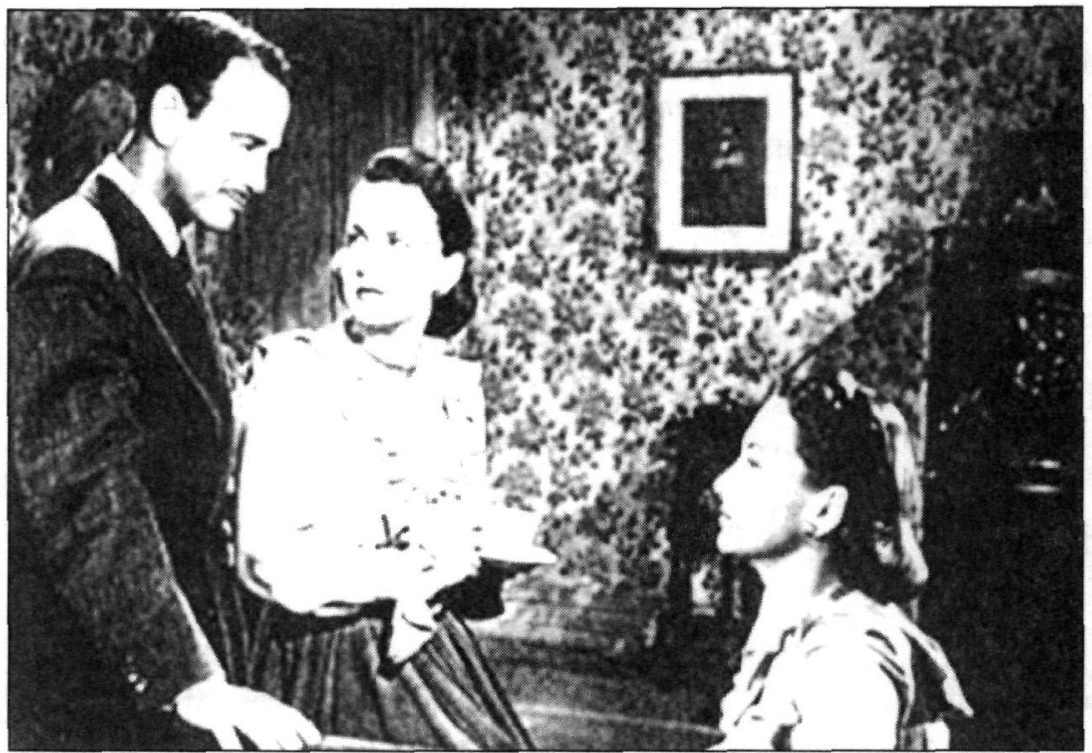

Figure 1: $\quad$ The Dark Mirror (Lew Ayres and Olivia de Havilland) ${ }^{2}$

Name-necklaces, lighting, and facial expressions help to identify the kind vs. psychotic twins.

When Scott invites the sisters to participate in his ongoing twins study, titles music accompanies the twins' conflicted views on accepting this situation. Ruth suspects that Terry's guilt will be revealed, but Terry believes that the study will provide a challenging environment in which to continue her machinations. Later, after Scott becomes romantically involved with Ruth, titles-related music accompanies their first kiss. Although this connection to the titles music doesn't initially make sense, it begins to do so as the camera angle changes and we realize that Terry is at the twins' apartment window, watching this. Later, minor key variations of the titles music accompany Terry's convincing lies that her sister has been dreaming, sobbing, and talking in her sleep. Similar variations accompany Terry's "music box hallucination" plans, as well as her plan to impersonate

2 From <http://www.sensesofcinema.com/contents/cteq/04/dark_mirror.html $>$. 
her sister and take over her identity. If she had succeeded in this, one could imagine Tiomkin constructing a new musical theme that simultaneously combined the separate falling/diatonic and rising/chromatic elements of his original opening titles theme. However, near the end of the film, Terry overtly implicates herself as insane (and thus also as the murderer), and a version of the existing, hybrid titles music confirms the twins' ongoing psychological connection (a kind of "split personality"), despite their newly-achieved separation.

A number of instances of source music and of mottos in underscore convey ideological identities for the two most important secondary characters of The Dark Mirror. For example, the "highbrow" psychologist Scott Elliott listens to relatively sophisticated, upscale nightclub music in public and to the first movement of Brahms' Symphony No. 4 (while working out chess moves!) at home. By comparison, the "lowbrow" detective Stevenson can't stand anything but "regular music," by which he presumably means 1940s' urban pop music, such as swing bands, crooners, and other types of vocal pop, and he sarcastically refers to the Brahms as the "wonderful" stuff. However, a "male bonding" mutual respect then develops between the "college boy" psychologist and the "street smart" detective as they work together to solve-through several categories of supposedly superior "male intelligence"-this murder case involving mysterious female twins. This aspect of the film closely parallels the attempts by a similar assortment of men in Bram Stoker's 1897 novel Dracula to eliminate an "evil" woman while also saving a "good" one. Darragh O'Donoghue (2004) has pointed out that the film's uncredited special effects creator, Eugen Schüfftan, had worked on F. W. Murnau's 1922 film Nosferatu (based on Dracula) and that there are a number of related visual effects in The Dark Mirror, such as a batlike inkblot image and additional lighting effects and character movements, that recall aspects of the earlier film.

Musically, the film also contains many overt, brief, "one-off" instances of underscoring-also known as "stingers." For example, Stevenson makes a comment that the potential murderer having been seen in several places at once makes about as much sense as Chinese music, and Tiomkin provides a very brief pentatonic/parallel passage with gong strike in order to evoke a stereotypical (arguably racist), cartoon-like "exotic" Far East. Similar instances of stingers also appear for the film's early visual of the doctor's murdered body (preceded by densely chromatic music as the camera surveys the murder scene, ending at the body), for Stevenson's first sight of the twins, for Ruth's word association of the word "mirror" with the word "death" (subconsciously revealing her sister's guilt), for a harrowing scene of Terry indicating her dangerous psychosis, for the first appearance of the word "insane," and for a large pair of scissors as a potential murder weapon. A stinger also appears for Terry realizing that her impersonation of Ruth has failed, which is followed by an orchestral build-up to depict her growing anger and her smashing of a mirror. In addition, during the Rorschach inkblot phase of Scott Elliott's twins' study, Terry sees cruel rivals and puppets in certain images, with the densely chromatic music of the underscore also suggesting that she is not mentally well. In the very same images, Ruth sees dancers, skaters, and old ladies (i.e., similar to what nearly everyone sees), with 
the pleasant, diatonic "ballet-like" music of the underscore suggesting that she, by comparison, is mentally normal. Rorschach images also appear during the opening credits and the brief ending credit, thus rivaling the film's related imagery of mirrors and reflections and of light vs. dark.

Early in the second half of The Dark Mirror, Terry cleverly makes use of source music emanating from a hidden music box in order to manipulate Ruth's fragile psyche into believing that she is hallucinating this. The use of the innocent, "twinkling" sound of a music box evokes associations with childhood, and it strongly adds to the sense that Terry's mental state of insane jealousy originated in the twins' early years together, when adoptive parents took in Ruth, but not Terry. However, the specific tune of this particular music box is decidedly adult-the well-known $19^{\text {th }}$-century American song "Frankie and Johnny," which is about a woman (Frankie) killing her two-timing husband. Although the song's lyrics are absent in a music-box rendition, its story is nonetheless somewhat comparable to Terry's "sibling rivalry" jealousies in this film. As Ruth hears the invisible music box music, she clasps her head in horror as she becomes convinced that she is hallucinating, and Tiomkin's score considerably heightens this with intense orchestral music to underscore (in both meanings) the fact that Terry has succeeded in psychologically taunting and manipulating Ruth. The tune then re-appears at the very end of the film, as Scott presents Ruth with that same (but now "harmless") music box. On the one hand, the erasure of Terry's manipulative activities-and of the related, earlier, intense orchestral music-might suggest that even "Frankie and Johnny" can be used as an innocent, child-like tune. On the other hand, it also seems likely that Ruth will remain psychologically connected to her sister, despite Terry's likely new status as a permanent patient of a state mental ward.

\section{Dead Ringer (PAul Henreid, 1964)}

\section{- "Don't You KNOW ME, Jim? I DIDN't KILl Frank DeLorca!"}

Dead Ringer features twins portrayed by Bette Davis (1908-89), who had earlier played rival twin sisters in the 1946 melodrama A Stolen Life and a rather similar character in 1962's What Ever Happened to Baby Jane? ${ }^{3}$ This film, by Davis's former co-star Paul Henreid (1905-92, who had also recently directed numerous episodes of TV's Alfred Hitchcock Presents), is set in Los Angeles. It includes André Previn's (b. 1929) underscoring theme associated with a premonition of bad things to come involving a poor, "lowbrow" twin Edith (Edie) killing her rich, "highbrow" sister Margaret (Maggie) and attempting to take over her life (see Example 2).

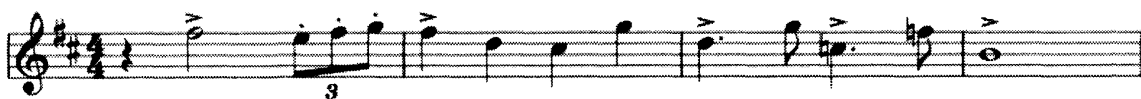

Example 2: "Premonition," Dead Ringer; music by A. Previn, transcribed by D. Bowman

3 Dead Ringer was written by Albert Beich, based on Rian James's story. In the U.K., it was released as Dead Image. It was also remade for television in 1986 as The Killer in the Mirror, starring Ann Jillian. 
This "flighty" and "gothic" theme at first features offbeat and triplet rhythms and step-wise motion giving way to a modestly-expanding "wedge" shape in its second measure. The theme's second half then balances this with dotted rhythms helping to emphasize the third beat of its third measure and the downbeat of its fourth measure. The theme's second half also contains a series of four melodic leaps, including two tritones, that pick up on the tritone of the end of the second measure's wedge, but chromatically inflecting (by modal substitution) the descent to the tonic, B. This music first appears during the film's opening titles, and it often appears melodically on a harpsichord accompanied by strings (or vice versa) and generally with quite strident supporting harmonies. The film mainly associates this music with Edie's jealousy of Maggie and with her resultant, misguided plan. The use of a harpsichord provides a sense of the "classic" (or "classical" or "out of time"), as though the creators of this film intended to recall similar, "timeless" stories from earlier centuries. Edie shoots her sister to death and then matter-of-factly exchanges all of her clothing with the dead body (as well as their hairstyles and jewelry) and poses the body-along with the gun and a credible handwritten note-in order to make it look like she herself committed suicide. The hard-to-accept plot device of this and nearly every twins' narrative (including The Dark Mirror, Sisters, and Dead Ringers) is that at least some people, even lovers and doctors (and lovers who are doctors!), at first don't seem to know that there are twins involved. In fact, all four films suggest that their twins have at some point (often including the present) exchanged identities in their work, dating, and/or sexual activities.

Previn's premonition theme accompanies an early scene in which Maggie's driver inadvertently provides Edie with the information that Maggie has just produced a terrible lie about having many years ago produced, with her wealthy husband Frank DeLorca, a son who then died in infancy. Badly-in-debt Edie has never stopped blaming Maggie for stealing Frank away from her almost twenty years ago, and she decides that Maggie's crass lie (i.e., to help save face, even on the day of Frank's burial) is sufficient grounds to kill her and replace her. As Edie leaves her apartment for the last time (wearing Maggie's mourning clothes and veil, see Figure 2), the strings-and-harpsichord theme accompanies this to let us know that things will not go well for her. Similarly, at Maggie's mansion, a version of this music accompanies Edie's first realization that there may be have been more to her sister's recent past than she has so far suspected. For example, an amorous birthday greeting arrives from Maggie's extramarital boyfriend.

Similar music accompanies the servants' unspoken realizations that the lady of the house has been replaced by her vengeful sister, as well as the related matter of Edie not knowing where "her" living room is, how to open "her" safe, what "her" usual drink is, who "her" boyfriend is, or how to sign "her" signature in order to settle the estate. Her rather extreme solution to the latter-burning her writing hand with a fireplace poker-is accompanied by a combination of this titles (harpsichord) music with ominous-sounding low strings and brass. Additional versions of this music accompany related scenes usually having to do with Edie being isolated from her true self, "out of her depth" within Maggie's world, and, in particular, thoroughly unaccustomed to a life of hidden criminal 
acts. Often, Previn arranges this music as "swirling" and active, but an early instance also inscribes a somewhat more plaintive variation in order to suggest the modest nature of Edie's apartment. Later in the film, he also begins to use the "gothic" harpsichord music for the disclosure of details about Maggie's own complicated life. Thus, the meaning of the opening title's music arguably has much less to do with what Edie knows she's getting into (i.e., killing her sister) than with what she doesn't know about (i.e., her sister's similar criminal past).

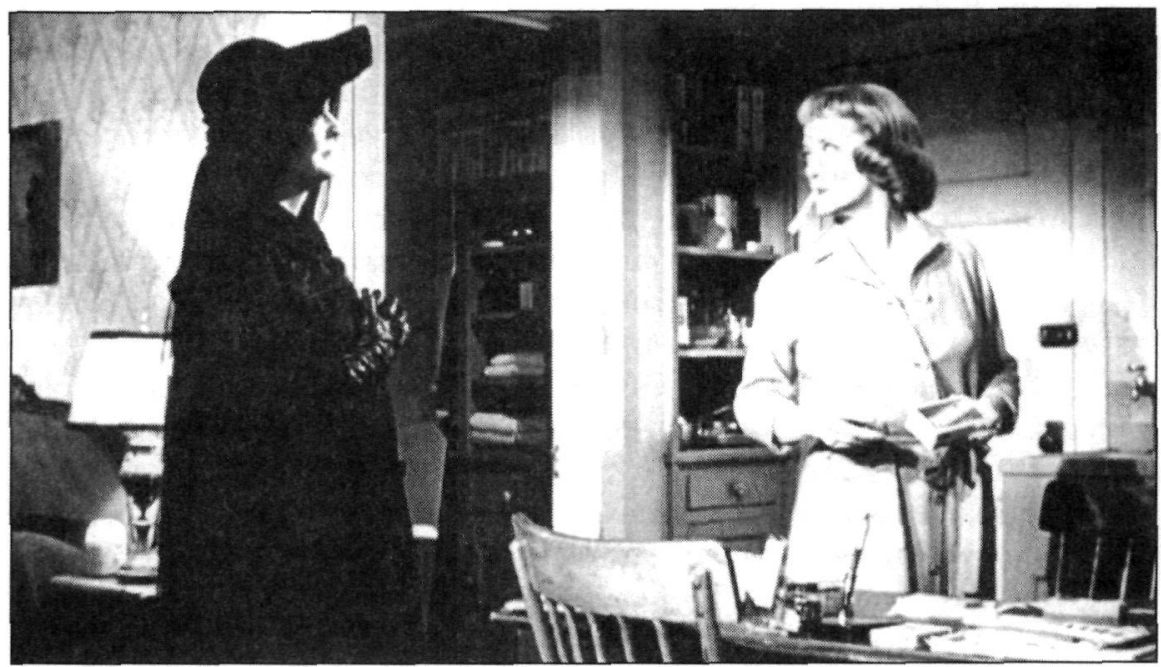

Figure 2: $\quad$ Dead Ringer (Bette Davis) ${ }^{4}$

The use of black and white cinematography would have been unusual in 1964 .

Edie's cramped apartment is above the cocktail lounge she runs.

The film also includes a secondary theme for the love of a policeman, Jim (portrayed by Karl Malden), for Edie. This love theme first appears near the beginning of the film, when he gives her a birthday present of a new watch (which she shortly thereafter transfers to the wrist of her sister's corpse). The theme include a leap upwards by a major sixth to a held note (B to G-sharp in $\mathrm{E}$ major), then faster-paced descending gestures in the direction of the starting note. In its final triplet gesture, it also inscribes the "yearning," Romantic era gesture of "flat VI" (a sort of "turn" figure on the bottom three notes of a C major scale) as it returns to the pitch B. In a slightly later scene, Previn suppresses this music, for Jim now begins to believe that Edie did actually commit suicide the previous evening. Later in the film, after weeks or months have passed, Edie gradually realizes that committing sororicide and impersonation for purposes of estate fraud has not been such a good idea, for she finds out that Maggie had led a surprisingly complicated life herself. Well into the second half of the film, Maggie's extramarital boyfriend returns from a lengthy trip overseas, and it becomes clear that he and Maggie had collaborated in Frank's murder by arsenic poisoning (which mimicked a heart attack). The boyfriend poses as a golf pro

4 From <http://smokingsides.com/asfs/D/Davis.html $>$. 
while actually carrying out jewel heists, and as he unearths Edie's deception he blackmails her for portions of Maggie's wealth. The film's earlier love theme appears as Edie resists his advances, which suggests that she is thinking of her own abandoned boyfriend (Jim, who had wanted to marry her). It also briefly reappears as Edie attempts to convince Jim of her true identity. The final appearance of the love theme occurs just before the end of the film, as Jim reconsiders her argument and attempts to make her admit it once again. However, by that point Edie has stoically resigned herself to Maggie's fate of the death penalty (now accepting it as her own fate), and the film aborts the love theme one last time. Edie's final line is highly reminiscent of "Mother's" line at the end of Alfred Hitchcock's 1960 film Psycho: "I'm Margaret DeLorca, Sergeant. As you said: 'Edie would never have hurt a fly." Musically, the "harpsichord" premonition theme then takes over the soundtrack in brief "stinger" variations.

Unlike Ruth's relatively tame "badness" in The Dark Mirror (co-dating men and sharing alibis), Dead Ringer eventually reveals that the rich and poor twins both had relatively evenly-distributed tendencies towards badness. Thus, the film primarily situates its estranged twins within the context of socio-economic jealousy rather than psycho-sexual jealousy. Edie initially runs a cocktail lounge called "Edie's," and for relatively early scenes in the film the soundtrack provides an organ-drum jazz combo comprising a young, African-American couple performing something like gospel-inflected "hard bop" jazz, with the woman playing a pedal-equipped electric organ and the man playing a drum kit. A loud example of such music serves to mask Edie's gunshot as she shoots Maggie, and throughout the surrounding scene in Edie's apartment there is nothing but source music for about twenty minutes of the film's running time. Most of this is from the jazz combo, but after the murder Edie channels the sisters' much earlier years by loudly singing the off-colour song "Shuffle Off to Buffalo" (from the 1933 film musical 42nd Street) in order to dissuade Jim from interrupting "them." These types of source music arguably signify a comparatively "lowbrow" context for Edie's life, and paying for the ensemble is, in fact, beyond her financial means. By comparison, once Edie takes over Maggie's life, light, sophisticated, "European" dance music (with violins, accordion, harp, and piano)-comparatively "highbrow" (i.e., Maggie's) music-accompanies her social events. A sub-plot involving a combination of somewhat strange religious and society "types" is also a part of this context, although this was already somewhat in evidence during the film's opening funeral scene, which also includes a chanted Latin requiem mass (sung by a priest and boy sopranos). This type of distinction between Edie and Maggie is quite similar to the "lowbrow" vs. "highbrow" music of Lieutenant Stevenson and Dr. Elliott in The Dark Mirror, except that Dead Ringer makes the equally interesting choice of transferring this sort of class differentiation to the twins themselves.

Dead Ringer contains very little of The Dark Mirror's "traditional Hollywood" sense of socio-economically contrasting males working together to solve the mystery of a woman (or, in this case, twin women). In fact, Jim is quite ineffectual both as a boyfriend and as an investigator, although it is equally true that he is less sexist than the policemen of The Dark Mirror. In a number of ways, he 
shows various characteristics of the kindness of The Dark Mirror's Ruth, and the film's three criminals (i.e., both twins and the golf pro boyfriend) are arguably all smarter than he his. Similarly, at least one music cue-of muted orchestral brasses-suggests that Frank DeLorca had also been comparatively "noble" and perhaps even "gullible." In Dead Ringer, no-one (male or female) is depicted as mentally ill, and it is Edie's and Maggie's criminal acts that are ultimately punished-rather than their "threatening" female intelligence. Essentially, they are punished because of their actual guilt, not because of "deductive" male intelligence. Stingers and other "one-off" music cues reinforce Edie's downward spiral throughout the film, such as for when we first see a medium-long "shocking" shot of Maggie's dead body posed as Edie, for when Edie-as-Maggie has to identify Maggie-as-Edie's body in the morgue, for the revelation that Frank was poisoned with arsenic, for accusations against Maggie and her boyfriend concerning this, for the boyfriend's death in a vicious attack by Maggie's dog, for the moment of "Edie's" sentencing (of capital punishment by lethal gas), and for a dirge-like march with ominous tympani and strings for when she leaves her sentencing on the way to death row.

The titles-based strings and harpsichord music also begins to implicate Edieas-Maggie as we become aware of the earlier activities of Maggie and her boyfriend. Similar music accompanies Edie's realization that abandoned Jim will not accept her "true" identity, as well as the butler's confession of knowing all along that she was an imposter. At the very end of the film (as Edie accepts her twisted fate), Previn abandons his reminiscence of the film's earlier love theme in favour of his titles-based music and a very brief film-ending flourish. Unlike the manipulative twin of The Dark Mirror, the jealous twin of Dead Ringer actually succeeds in taking over her sister's life-even to the point of accepting the consequences of a murder she did not commit in lieu of the consequences of a murder she did commit. Ultimately, the film is thus a kind of "morality tale" crime drama in which the rich and poor, equally-bad twins both have to die, unlike the earlier film's "redemption tale" psychological drama of separating a psychotic, intelligent, and inherently bad twin from an almost entirely good twin.

\section{Sisters (Brian De Palma, 1973)}

\section{— “THE NORMAL TWIN CAN ONLY BE SO BECAUSE OF HER DISTURBED SISTER."}

Sisters features formerly conjoined (or "Siamese") and orphaned French Canadian twins portrayed by English Canadian actress Margot Kidder (b. 1948). ${ }^{5}$ The film, set mainly in New York City's Staten Island, includes one of the final scores by former Alfred Hitchcock collaborator Bernard Herrmann (191175). According to director Brian De Palma (b. 1940), film editor Paul Hirsch

5 The film was written by Brian De Palma and Louisa Rose, based on De Palma's story. It was released in the U.K. as Blood Sisters and remade for theatrical release in 2006. Margot Kidder starred in Bob Clark's 1974 Canadian suspense thriller Black Christmas (which was originally released in the U.S. as Silent Night, Evil Night), and she then became a major star as Lois Lane in the four Superman movies from 1978 to 1987. 
had temporarily tracked selected scenes of Sisters with some of Herrmann's music from Hitchcock's 1958-64 films Vertigo, Psycho, and Marnie (Rubenstein 1973). Thus, the filmmakers were exceptionally fortunate in being able to engage Herrmann himself (an American, though living in London at the time) to score their film. ${ }^{6}$

Herrmann's opening titles music for Sisters recalls his theme for Hitchcock's 1958 film Vertigo (a suspense film also involving a "twin-like" confusion of identity), and they include images of a pair of unborn Siamese twins that also somewhat evoke the "arty" visual style of the earlier film's opening titles. The film's obsessive investigation by the female reporter and murder witness, Grace (portrayed by Jennifer Salt), recalls Hitchcock's 1954 film Rear Window. The latter part of the titles music is orchestrationally dense, harmonically dissonant, and also includes the use of a Theremin or else a similar-sounding synthesizer. In the 1940s and 1950s, directors and composers often associated the "otherworldly" Theremin with instances of psychological distress-or, in the case of Herrmann's score for Robert Wise's 1951 film The Day the Earth Stood Still, with science-fiction. Miklos Rozsa, in his Oscar-winning score for Hitchcock's 1945 film Spellbound (which involves yet another confused identity), consistently ties the use of the Theremin to a particular visual phobia. Sisters associates similar electronic sounds with the physical and ongoing psychological depth of the Siamese nature of its twins. For example, this type of music accompanies our first sight of gentle/normal Danielle's separation scar (as she makes love with her new boyfriend). The same type of music participates in the activities of disturbed and vicious "Dominique" (see Figure 3), including her murder of Danielle's boyfriend Phillip (portrayed by African-American actor Lisle Wilson) and, near the end of the film, for drug-induced dreams of physical separation and further evidence of psycho-sexual and homicidal tendencies.

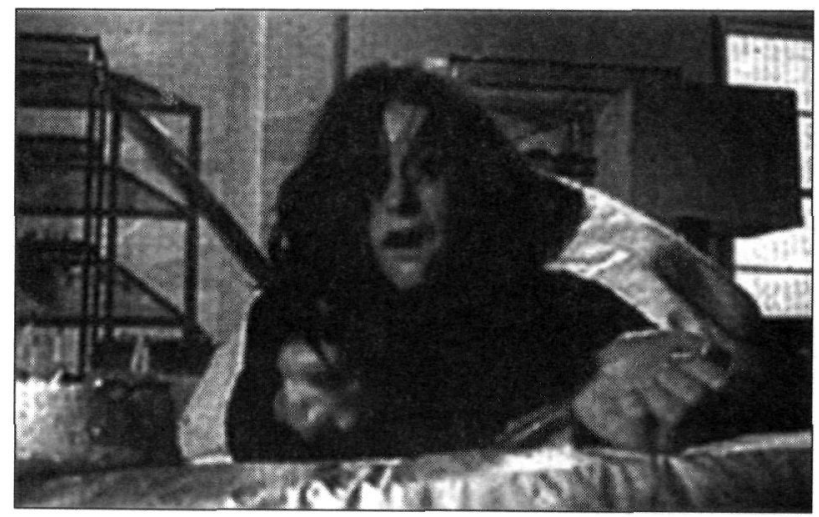

Figure 3: $\quad$ Sisters (Margot Kidder) ${ }^{7}$

6 In terms of characters and plotlines, De Palma's later films Obsession (1976), Dressed to Kill (1980), and Body Double (1984) also strongly evoke Hitchcock's work from 1954 to 1964.

7 From <http://www.briandepalma.net/sisters/sisint.htm >. 
Herrmann associates a winds-based version of the opening motif of his titles music (adjacent, broken, descending thirds; comparable to his main theme for Vertigo) with the ongoing complicity of Danielle's ex-husband, Emil (portrayed by William Finley), in the activities of the twins. For example, this music appears as Emil spies on Danielle, and it also appears as he participates in concealing the murder victim's body and in removing other evidence of the crime. Later, the same music accompanies a scene in which (per his instructions) the couch containing Phillip's body is loaded onto a truck. Shortly thereafter, it also accompanies the scene in which we discover that Emil is, in fact, the doctor who separated these Siamese twins (as adults) so that he could marry Danielle and attempt to have a child with her. The score bases a variation of this windsbased music on homorhythmic statements of the underlying thirds and semitonal proximity within the main motif. This occurs in an early scene within the film, as Phillip pretends to leave in order to "shake" snooping ex-husband Emil, as Danielle awakens the next morning in desperate need of her medication, and as Phillip accidentally knocks her last two pills down her bathroom sink-with disastrous consequences.

A third type of related music reprises a chromatically-descending, full orchestral passage from the end of the opening titles-where it had accompanied visual depictions of Siamese twins. This "separation" or "knife" music variant also participates as we see Danielle's separation scar, as "Dominique" repeatedly stabs Phillip, as Emil hides the knife and related evidence in his car, as such a knife is searched for in the apartment, and upon the later discovery of evidence that there are (or were) Siamese twins. Near the end of the film, at the ethically-dubious institute where Danielle and Dominique lived and were surgically separated, the same music accompanies "Dominique's" final act of murderwhich involves a surgical scalpel as a substitute for a knife in her gruesome stabbing death of Emil. This implies-musically and otherwise-that Emil had "transferred" aspects of Dominique's psyche to Danielle (with a knife) and that Phillip-by sexually encountering her and accidentally displacing her medication-has inadvertently re-created Dominique. (It makes much less sense that Emil would have intentionally "awakened" her.) In an earlier scene, the snooping reporter Grace experiences a horrific dream while under drug-induced sedation, administered at the institute by Emil. That sequence, in which she dreams she is one of the conjoined twins, was originally tracked with orchestral, dreamrelated music from Herrmann's score for Hitchcock's Vertigo, but the final version recalls the earlier "knife" aspect of Sisters' opening titles music as well as the strident electronic sounds of its earlier murder scene. Shortly later, Emil also hypnotizes Grace so that she will forget everything about having witnessed the murder of Phillip, and Herrmann's "mind control" music includes creepy windbased gestures (such as turn and sigh figures) combined with rising chromatic string music.

Unlike the use of surrounding lowbrow vs. highbrow source music in The Dark Mirror and in Dead Ringer, Sisters uses dance club music in an early scene to establish a sort of "middle-brow" sociological context. That music, featuring piano, drums, and percussion (and almost certainly not provided by Herrmann), 
sounds something like Herbie Hancock's world-music inflected jazz-pop fusion of the early 1970s. Dinner at that club, the Africa Room, is Phillip's prize for acting in the film's TV-show-within-the-film opening scene of a sleazy game show called Peeping Toms, and Danielle's prize for the same is an elaborate kitchenknife set. After the opening titles, the film actually begins with a "teaser" scene from Peeping Toms that the audience would at first assume is part of the actual narrative of the film. However, once that façade is broken, the film provides "cheesy", swirling organ music as a TV theme, as well as "waiting/thinking" music (similar to the example of this from the TV show Jeopardy) and novelty soundeffects (such as a slide-whistle). Similarly, in a later part of the film Herrmann provides music for a film-within-the-film documentary about the twins, which thus paradoxically causes it to function as source music at the same time that it functions as underscore. Visually, De Palma also similarly plays with conventional narrative expectations by occasionally using split-screen effects in order to provide supplemental information or else to establish simultaneous pointsof-view on a particular scene.

In Sisters, Herrmann includes various instances of recurring underscore, such as a romantic love theme to set the mood for Danielle and her new boyfriend Phillip early in the film, as they take the ferry from Manhattan to her apartment in Staten Island (a hilly, harbour-adjacent stand-in for Vertigo's San Francisco). Similar music appears as the lovers wake up the following morning. (Film editor Paul Hirsch originally tracked these scenes with some of Herrmann's music for comparable scenes in Hitchcock's Marnie.) An off-screen argument between the twins is overheard (in French, but subtitled into English), and we also then find out that this is the twins' birthday-which recalls the initial birthday context of the twins in Dead Ringer. Phillip goes out and purchases a cake (his primary task is to pick up Danielle's prescription refill), and a "birthday-cake" theme (played on an innocent, child-like, music-box celeste; see Example 3a) accompanies its cake-shop inscription to Dominique and Danielle. In fact, phrases of this music alternate with "groaning" chords that accompany interleaved shots of Danielle's simultaneous psychological transformation into Dominique. A related two-phrase unit-following the first musical "groan"-modifies the initial birthday cake motif into its parallel minor (see Example 3b), which suggests two parallel aspects (or differentiated "twins") of the same theme.

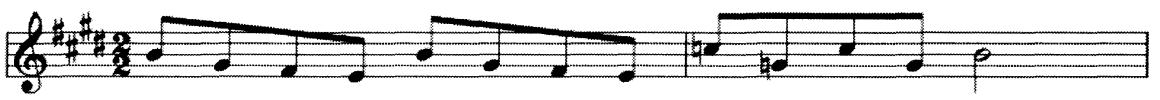

Example 3a: "Birthday Cake," Sisters, opening measures, E major with "flat VI"; music by B. Herrmann, transcribed by D. Bowman

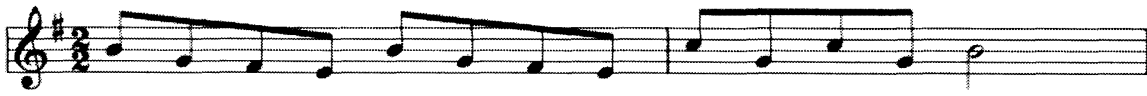

Example 3b: "Birthday Cake," Sisters, parallel minor version (E minor); music by B. Herrmann, transcribed by D. Bowman

This music features the same use of "flat VI" as in the love theme of Dead Ringer (C major within the key of E major). Franz Schubert (1797-1828) fre- 
quently used this same type of harmony, such as in the fifth (second-last) stanza of "Der Lindenbaum" from his 1827 song cycle Winterreise, which is otherwise in E major or else its parallel, E minor. In the fifth stanza, which heavily gravitates towards $\mathrm{C}$ major, cold winds persistently conspire (by reorienting the "leaf fluttering," triplet, $16^{\text {th }}$-note figures also present in the song's piano introduction and ending) to blow the narrator towards a linden tree that is now barren of its pleasant associations-and of its leaves-and thus signifies his imminent death. In a much more concise version of this, Herrmann tells us precisely the same thing about what will happen to the bearer of the birthday cake, and, indeed, this music continues as Phillip brings the cake back to Danielle's apartment. After a rather quiet interval in which Phillip prepares to serve the cake (including a large knife for cutting it), Herrmann provides one of the most intense music cues of his long career. For the scene in which "Dominique" brutally attacks and kills Phillip, Herrmann's music comprises a highly jolting and frantic combination of horrific swirling effects, groaning orchestral descents, swooping electronic sounds, ominous bell sounds, and even echoes of Dominique's voice. Film editor Hirsch probably originally tracked this scene with Herrmann's "shrieking strings" from Hitchcock's Psycho (in which a pair of similarly brutal stabbing incidents occur), but the equivalent vision in De Palma's later horror film is much more ornate.

In Sisters, variations of Herrmann's birthday cake music also re-appear during an investigation at the cake shop and, at the very end of the film, as a private investigator (hired by Grace's newspaper) spies on the delivery in rural Quebec of the sofa-bed containing Phillip's corpse. This leaves the impression that there will be additional lovers, birthdays, transformations, and murders. The Dark Mirror recontextualizes its "music box music" at the end of the film (although with unclear implications), and Dead Ringer reprises and quickly aborts its love theme in order to underscore a decidedly bleak ending. By comparison, Sisters reprises its birthday cake music in order to deny a conventional narrative closure entirely, as the alternating major and minor versions of the birthday cake music at the very end of the film strongly suggest the continuing existence of both twins. Thus, the film is a sort of "horror tale" psychological thriller, featuring the repercussions of an elaborate "crazy scientist" variation of the psychologist Scott Elliott having separated Ruth from Terry in the second half of The Dark Mirror.

\section{Dead Ringers (David Cronenberg, 1988)}

\section{- "WE ARE PERCEIVED AS ONE PERSON."}

Dead Ringers features Jeremy Irons (b. 1948) as twin, male gynecologists. Director David Cronenberg (b. 1943) and Norman Snider based their screenplay on Bari Wood and Jack Geasland's Twins: A Novel (1979). The film does not contain any music comparable to the music box, love, birthday cake, and other musical themes involved in the earlier three films. Howard Shore's (b. 1946) slow, brooding, brass-heavy opening titles music accompanies titles' information as well as body and twins-related images alternating with equally-strange 
images of gynecological instruments. After this, the film's first fifteen minutes includes no underscore music and only one subtle instance of source music: a soprano opera aria piped in as background music at a restaurant. The film's first two scenes provide a pair of evocative backdrops (Toronto, Ontario in 1954 and Cambridge, Massachusetts in 1967) in order to establish the twins' strange and extremely close bond as adolescents as well as their "top-of-the-class" status as medical school graduates and, concurrently, as gynecological instrument designers. For the rest of the film, set almost entirely in Toronto, the twins still live together and run a female fertility clinic together. A substantial portion of the film therefore involves scenes with the twins in frequent dialogue, and Jeremy Irons' dual performances are thus quite remarkable.

As the "film proper" begins in the present (1988), the somewhat more extroverted, suit-wearing, and "public relations" twin, Elliott, gets to know a new patient who is also a well-known actress named Claire (portrayed by French Canadian actress Geneviève Bujold). ${ }^{8}$ Elliott has sex with her (although this is not shown), but he then "gives" her to his somewhat more introverted, sweaterand glasses-wearing, "clinician" twin, Beverly, who had actually met and examined Claire first. ("Fertility doctor" twins exchanging identities and dating a patient for sexual purposes substantially complicates the situation of The Dark Mirror's "twins researcher" becoming personally involved with some of his patients.) Beverly uncharacteristically asserts his desire to develop a continuing relationship with Claire, and he inadvertently mentions to her that he has a brother (although he does not reveal that they are twins) and early in the film suggests that he and his brother are not at all the same psychologically. As we see Beverly and Claire having "Elliott-style" bondage sex (involving Claire being tied up with surgical tubing), Shore provides music in the winds and strings that he then varies and reapplies for similar elements later in the first half of the film. (For the next ten minutes after this, the only music is one brief example of source music: a theme for a TV newsmagazine.) Claire begins to sense that there are "two sides" to Beverly, a "society" friend informs her that the brothers are twins, and she then confronts them about their questionable ruse of sharing an identity in order to facilitate sexual encounters.

Shore treats his wind/string "theme" quite flexibly and initially presents it in something like ABA form, with the B section up a semitone. Later, as Beverly and Claire begin to take drugs together, he expands the range of this music to include a lower fifth. He then continues to expand this music in both directions to include the minor sixth above and a semitone below (thus inscribing harmonic minor). This takes place as Beverly gets hooked on drugs while Elliott is temporarily away on business and while Claire refuses to resume their relationship. When Beverly chances upon her at an art gallery, the upper minor sixth returns, but now associated with high strings. Subtle thematic transformations such as this recall Richard Wagner's $19^{\text {th }}$ century conception of flexible Grundthemen rather than the "classic" film scoring practice of easily and consistently signifying leitmotifs. Indeed, the ambiguity and constant variation within Shore's

8 Bujold had earlier starred in Brian De Palma's 1976 Vertigo-like suspense film Obsession. 
harmonic minor "theme group" also allows him to use it as transition music between scenes and settings otherwise involving the same characters. For example, similar music underscores Beverly's horrific dream of being attached to his brother as Siamese twins, and his drug abuse subsequently causes his clinical abilities to suffer (reducing him to Elliott's less-skilled level) while his paranoia and dementia also grow. He starts referring to himself generically as "one of the Mantle twins," shoots up drugs while at work (even before performing operations), and commissions an artist to construct his new series of gynecological instruments for operating on "mutant women."

Elements of the score's thematic ambiguity demonstrate Cronenberg's impressions regarding the nature of earlier twins films, that The Dark Mirror was, for example:

a traditional twins story about a crazed killer and an innocent naive twin, and I had already realized that most twins stories were either that or they were broad comedies, with both twins exactly the same.... I would want it to be about two real complex human beings, neither one of which is all good or all bad. (Cronenberg 1996, n/p)

To emphasize this aesthetic, Cronenberg deemed certain of the source novel's differentiations inappropriate, inasmuch as he mainly wanted to stress the twins' similarities and their quite subtle differences. For example, the novel Twins differentiates the twins by portraying one of them as gay, by including a sex scene between them, and also by providing a plot twist involving one of them getting married. In Dead Ringers, by comparison, Beverly and Elliott instantiate similar levels of psychological integration and complexity, as "two halves of the same person"-but, in the second half of the film, increasingly indistinguishable halves. Similarly, Howard Shore's music convincingly eschews the traditional "good vs. evil" uses of differentiated leitmotifs and other music. In the earlier three films, the twins all have a certain sense of being two halves of the same person, but they are also much more greatly differentiated in terms of character attitudes (dialogue, facial expressions, etc.), film aesthetics (such as lighting choices), and music.

Contrasting the "middle-brow" socioeconomic coding of Sisters and the "split" coding of The Dark Mirror (detective vs. psychologist) and Dead Ringer (poor twin vs. rich twin), Dead Ringers provides several instances of operatic music quietly in the background at fancy restaurants and similar bars for scenes involving both twins. This, along with their interest in the visual fine arts, provisionally associates both twins with "highbrow" culture. However, an early segment in the film's second half foregrounds a 1956 doo-wop song-the Five Satins' "In the Still of the Night (I'll Remember)" - as the twins and Elliott's girlfriend (not Claire) dance erotically just prior to Beverly collapsing from a near-fatal drug overdose. As he falls to the floor, orchestral string/wind underscoring re-appears, thus taking over from the pop song. The song can therefore be seen either as source music or as "imagined music," although Elliott certainly does subtly move to its tempo. In any case, it is a sign of Dead Ringers' postmod- 
ern nature that the film associates its twins both with "high" culture and with popular culture.

By far the majority of the settings in Dead Ringers are interiors, which emphasizes the "interiority" of the twins' continuing psychological fusion and also parallels the way in which the fact the twins are gynecologists underscores a focus on the insides of female bodies. The score's thematic ambiguity also inscribes a kind of musical interiority. The fact that the twins "don't do husbands"-as explained to a distraught patient-forces Cronenberg to avoid exteriors and Shore to avoid consistently-signifying leitmotifs. Claire, who is caught up in all of this, has a "fabulously rare" trifurcated womb and is therefore unable to bear children. This is a fascinating interior, considering that the twins are fertility specialists. Near the end of Dead Ringers, the twins' interiorities have themselves become "synchronized" as equally drug-dependent and deranged. In one scene, they traipse across a room in exactly parallel steps and in exactly the same state of partial dress, without the audience being able to tell which is Beverly and which is Elliott (see Figure 4).

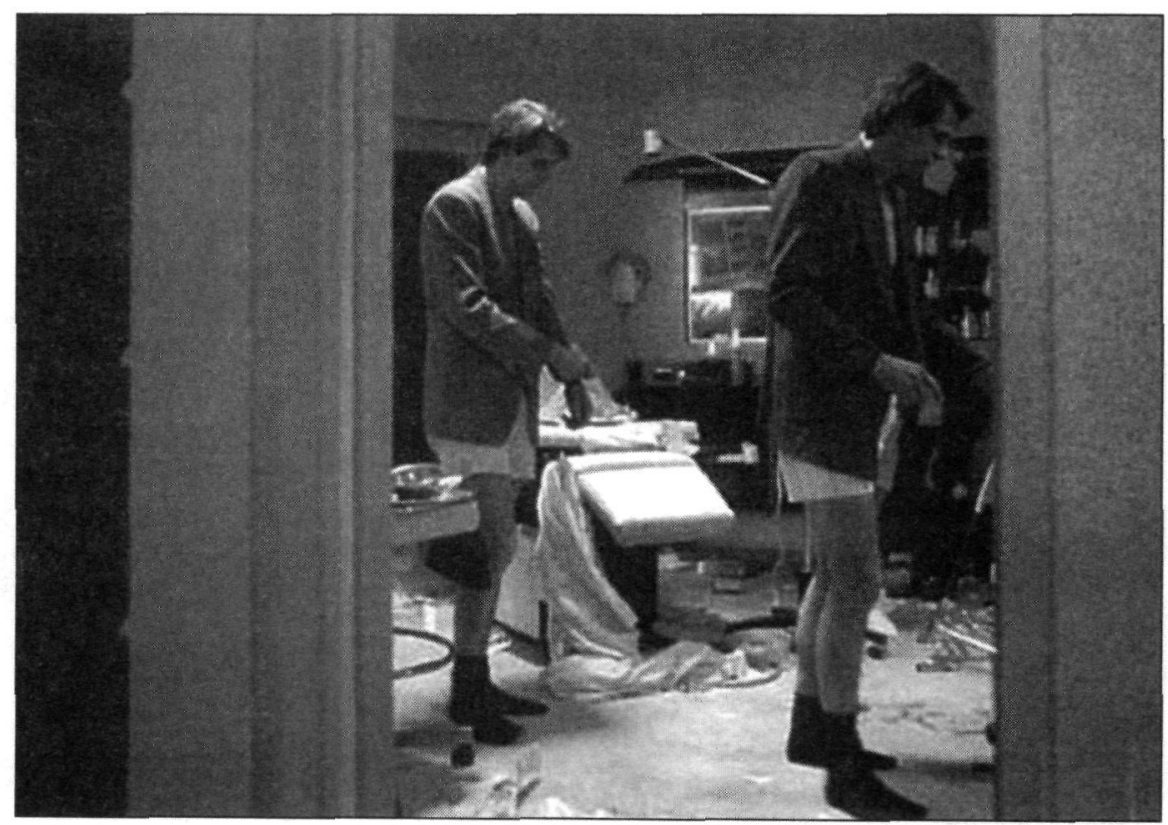

Figure 4: $\quad$ Dead Ringers (Jeremy Irons) ${ }^{9}$

This final day of the film's timeline is also the twins' birthday, and they regress into a rather child-like state as they share some cake. Cronenberg thus inverts the "plot precipitating" birthday contexts of the beginnings of Dead Ringer and Sisters for a kind of "character fusion summation" very near the end of Dead Ringers. Around this time, Shore reorients his opening titles music as "murder/ suicide" music, and Beverly uses one of his "mutant" tools to stab his imagined

9 From <http://www.widerscreen.fi $>$. 
"Siamese twin" fatally in the abdomen. Shore incrementally reconstructs his music rhythmically, then melodically and texturally. After a brief exterior shot during which deranged Beverly aborts his last-ditch effort to communicate with Claire (by means of a pay phone), he returns to the clinic and "fuses" with his brother-in a visually stunning overlap of two versions of Jeremy Irons. The twin' references to the famous $19^{\text {th }}$ century Siamese twins (1811-74) in Dead Ringers suggests a reorientation of Chang dying and then Eng dying "of fright" from this. Instead, Beverly kills Elliott and then becomes psychosomatically conjoined with him in death. A version of the full titles music then finally emerges, in an extension of its original form and for the several minutes of the end titles.

The titles music comprises a slow-moving brass and strings theme, of which the opening melodic notes focus on mediant, supertonic, and subdominant pitches within D major (see Example 4a). The music of the end titles is nearly identical to this. However, the final measures gently suggest the chromatic string music that had earlier accompanied the first stages of the twins' fusion. Towards the end of the film, drug-craving Beverly shaves his face before managing to sneak out from where Elliott has confined him in their now-defunct clinic. The accompanying music (see Example $4 \mathrm{~b}$ ) begins to mediate between the chromatically-descending string music generated by Beverly's separation from Claire and the diatonic, titles music gradually reoriented as "murder/suicide" music. As Elliott expires and Beverly awakens from what he believes was another dream, music reminiscent of the opening titles' music appears for the first time in more than one hundred minutes. Then, in the final minute or so before the end title, the score begins to express D minor, at first vertically (see Example 4c) and then horizontally (see Example 4d).

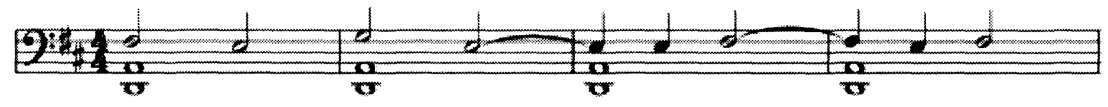

Example 4a: Opening titles music of Dead Ringers, mm. 1-4;

music by $\mathrm{H}$. Shore, transcribed by $\mathrm{D}$. Bowman

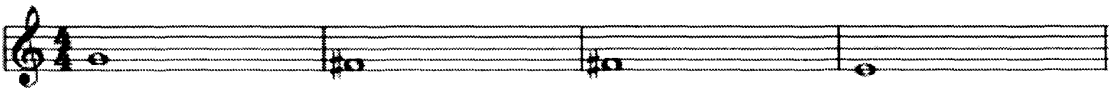

Example 4b: First stage in reorienting the Dead Ringers titles music, ca 1:32:00; music by $\mathrm{H}$. Shore, transcribed by $\mathrm{D}$. Bowman

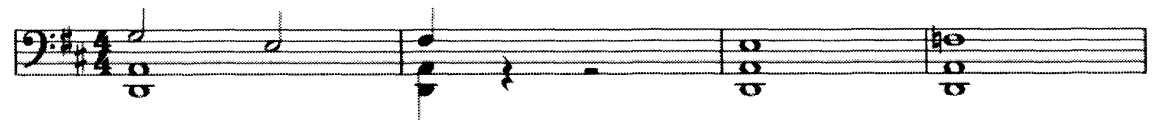

Example 4c: Second stage in reorienting the Dead Ringers titles music, ca 1:47:00; music by $\mathrm{H}$. Shore, transcribed by $\mathrm{D}$. Bowman 


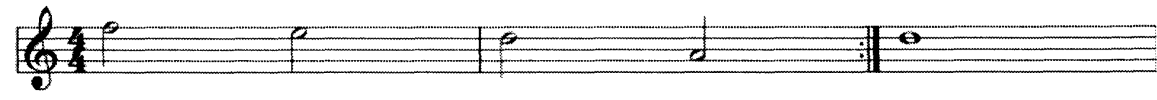

Example 4d: Third stage in reorienting the Dead Ringers titles music, ca 1:51:00; music by $\mathrm{H}$. Shore, transcribed by $\mathrm{D}$. Bowman

The reappearance and reorientation of the long-absent opening titles music provides a circularity to the structure of the film. The overlap of the two bodies visually supports this, which also evokes the images of Siamese twins and gynecological instruments shown in the opening titles.

Shore claims that he "wanted to create a score... that didn't underline [the film] too much emotionally" (Brown 1994, 341). Similarly, Cronenberg claims that "the tone of [the music for Dead Ringers], like the tone of... dreams, is ineffable. You cannot speak of it" (Cronenberg 1996, 149). However, this "ineffability" in fact has precisely to do with the fact that Cronenberg depicts his twins as becoming psychologically, not physically, Siamese and as co-dependents, not opposites. Cronenberg and Shore thus increasingly avoided "separating" the twins and then ultimately fused them together. As was fairly normal until recent decades, the earlier three twins films end very abruptly-thus narratively privileging the music immediately preceding the films' brief end flourishes. By comparison, Cronenberg makes excellent use of the recent convention of lengthy end titles in order to steep the audience in the film's quite murky endtone. The very end of the closing credits then shows a final image of twins in a womb, which suggests that Beverly and Elliott have, at the point of their deaths, conceptually reverted to a fusion as far back as that.

Cultural theorist Jean Baudrillard (1929-2007) has suggested that at the height of its coherence, a system is haunted by an abyss of reversal and that a simulation is played against death (Baudrillard 1988, 123). In Dead Ringers, the twins achieve a height of coherence through an elaborate system of simulating and impersonating one another. By the end of the film, they have become fused to one another in the "abyss of reversal" of murder-suicide, regression, and conjoined death. This also necessitates a parallel musical fusion. Elsewhere, Baudrillard suggests that:

[t]o the "free" individual, the divided subject, there corresponds the vertical madness of yesteryear: psychical madness, the transcendent madness of the schizophrenic, that of alienation,.... To the identitary individual, that virtual clone, there corresponds a horizontal madness,...: the delirium of genetic confusion, of the scrambling of codes and networks, of biological and molecular anomalies, of autism... the delirium not of the schizophrenic but of the isophrenic, without shadow, other, transcendence or image-that of the mental isomorph, the autist who has, as it were, devoured his double and absorbed his twin brother. (Baudrillard 1994, 109)

In Dead Ringers, Beverly and Elliott become delirious and genetically confused. In Baudrillard's terms, they become horizontally scrambled, shadowless "isomorphs," devouring and absorbing each other. 


\section{CoDA}

In many other of his films, such as 1977's Rabid, 1979's The Brood, 1983's Videodrome, 1996's Crash, 1999's eXistenZ, and 2002's Spider, David Cronenberg also firmly embraces aspects of postmodernism. In fact, he includes thematic elements of horror, sexuality, the body, dreams, reality, and/or mediation in all of his films, even when he begins with material originally written by someone else. However, he does not always approach these themes by way of postmodernism. For example, his 2005 film A History of Violence primarily articulates the inner struggle of a small-town family man (portrayed by Viggo Mortensen) whose suppressed hit-man past is inadvertently awakened through his own heroicand "uncharacteristically violent"-act. ${ }^{10}$ For the film's early scenes of a bucolic "American dream," Howard Shore's score prominently uses "noble-sounding" music in a major key, mainly featuring orchestral brass instruments and diatonic, rising gestures. As the character's past begins to impinge on his present, Shore aborts this music in favour of his more characteristic "brooding" style of descending, sigh-like, and dissonant gestures. That second type of music remains to underscore the uneasy situation also suggested by the facial expressions of the film's speech-less closing scene. In that scene, the main character returns from having murdered his gangster brother in order to join his family at home for dinner. After much of the film's running time and an appropriately reflective delay into the end credits, the earlier "noble" music finally reappears to amplify the subtle aspects of hopefulness within that otherwise ambiguous closing scene. This suggests that Cronenberg has not exclusively embraced postmodernism.

Dead Ringers demonstrates Royal S. Brown's argument that "the final phase in the postmodernization of the film/music relationship" is one in which "image[s] and music move on parallel planes" so that the implications of the musical images coincide with-rather than underline-the visual images (Brown 1994249 , 253). By comparison, The Dark Mirror, Dead Ringer, and Sisters contrast, anchor, and/or differentiate their twins, and $A$ History of Violence similarly differentiates the "normal" version of its main character with his "abnormal" past. These films accomplish such contrasts through such mechanisms as psychosis, jealousy, and split personalities. They also do so with the help of clearly-differentiated musical themes or, in the case of $A$ History of Violence, a theme that completely disappears until a kind of "reset mechanism" causes it to reappear during the film's end titles. Such an approach works perfectly well within those four films, but a strategy of greater thematic/musical complexity and postmodernism also certainly works very well within Dead Ringers.

10 The film is based on John Wagner and Vince Locke's graphic novel, with a screenplay by Josh Olson. The film's duration is 96 minutes. 
REFERENCE LIST

\section{FILMS}

Cronenberg, David, director. 1988. Dead Ringers. 2005. A History of Violence.

De Palma, Brian, director. 1973. Sisters.

Henreid, Paul, director. 1964. Dead Ringer.

Siodmak, Robert, director. 1946. The Dark Mirror.

\section{BIBLIOGRAPHY}

Baudrillard, Jean. 1994. "How can you jump over your shadow when you no longer have one?" In The Illusion of the End. Translated by Chris Turner. Cambridge: Polity Press. . 1988. Selected Writings. Translated by Jacques Mourrain. Edited by Mark Poster. Stanford: Stanford University Press.

Brown, Royal S. 1994. Overtones and Undertones. Berkeley: University of California Press.

Cronenberg, David. 1996. Criterion laser disc edition of Dead Ringers, special features. New York: Voyager Company.

O'Donoghue, Darragh. 2004. "Senses of Cinema: The Dark Mirror." See <http:// www.sensesofcinema.com/contents/cteq/04/dark_mirror.html>.

Rubenstein, Richard. "The Making of Sisters: An Interview with Brian De Palma." Filmmakers Newsletter, September 1973. See <http://www.briandepalma. net/sisters/sisint.htm>.

\section{ABSTRACT}

This paper compares the modernist musical-narrative separations of The Dark Mirror (Robert Siodmak, 1946), Dead Ringer (Paul Henreid, 1964), and Sisters (Brian De Palma, 1973) with the postmodernist musical-narrative fusions of the Canadian film Dead Ringers (David Cronenberg, 1988). The two earlier films (starring Olivia de Havilland and Bette Davis, respectively) mainly conform to the aesthetic of film noir or "suspensethriller," whereas the two later films (starring Margot Kidder and Jeremy Irons, respectively) also contain substantial elements of "horror." The musical scores of these four films (by Dimitri Tiomkin, André Previn, Bernard Herrmann, and Howard Shore) feature, in varying degrees, the meaningful placement and development of leitmotifs and titles music, changes in meaning by altering instrumentation and/or mode, gender representations, and issues of cultural hierarchy and class distinctions.

\section{RÉSUMÉ}

Cet article compare les séparations musicaux-narratives modernistes de The Dark Mirror (Robert Siodmak, 1946), Dead Ringer (Paul Henreid, 1964), Sisters (Brian De Palma, 1973) et les fusions musicaux-narratives post-modernistes du film canadien Dead Ringers (David Cronenberg, 1988). Les deux films les plus anciens (mettant en 
vedette respectivement Olivia de Havilland et Bette Davis) sont en conformité avec l'esthétique du film noir ou "suspense-thriller " alors que les deux plus récents (mettant en vedette respectivement Margot Kidder et Jeremy Irons) contiennent également des éléments substantiels d' " horreur ». Les trames musicales de ces quatre films (composées par Dimitri Tiomkin, André Previn, Bernard Herrmann et Howard Shore) mettent en évidence, à des degrés divers, le positionnement approprié et le développement de leitmotifs et de thématiques musicales, des changements de significations par modifications de l'instrumentation et-ou du mode, des représentations par genre et des marques établissant une hiérarchie culturelle et des distinctions de classes. 